Прокопів М.M.

\title{
Оцінка лікарями-неврологами стаціонарної медичної допомоги при церебральних інсультах (за результатами соціологічного дослідження)
}

\author{
Національний медичний університет імені О.О. Богомольця, м. Київ, Україна
}

prokopivmm@gmail.com

\author{
Прокопив М.M. \\ Оценка врачами-неврологами стационарной \\ медицинской помощи при церебральных инсультах \\ (по результатам социологического исследования) \\ Национальный медицинский университет \\ имени А.А. Богомольца, г. Киев, Украина
}

\section{Prokopiv M.M.}

Doctors-neurologists' assessment of in-patient medical care for patients with cerebral stroke (after the results of sociological research)

National Medical University named after O.O. Bohomolets, Kyiv, Ukraine

\section{Встуі}

В Україні продовжується реформування системи охорони здоров'я [1]. Попередні етапи передбачали пріоритетний розвиток первинної медико-санітарної допомоги на засадах загальної лікарської практикисімейної медицини [2]. 32018 року проводиться робота 3 впровадження затвердженої Законом України «Про державні фінансові гарантії медичного обслуговування населення» програми гарантованої медичної допомоги для чого розроблені та затверджені пакети медичних послуг [3-5].

Окремим пакетом медичних послуг $\epsilon$ пакет медичного забезпечення при гострих мозкових інсультах впровадження якого має на меті підвищення якості та ефективності медичної допомоги.

Вивчення стану організації медичної допомоги населенню при гострих мозкових інсультах і визначило актуальність даного дослідження.

Мета - дослідити та проаналізувати рівень оцінки лікарями-неврологами стаціонарної медичної допомоги при церебральних інсультах в закладах охорони здоров'я міста Києва.

\section{Матеріали та методи}

Матеріалами дослідження слугували результати соціологічного опитування 119 лікарів-неврологів м. Києва які забезпечують надання стаціонарної допомоги пацієнтам при церебральних інсультах. Дослідження проводилося за спеціально розробленою анкетою. Дані про респондентів наведено в табл. 1 .

При проведенні соціологічного дослідження були дотримані принципи Гельсінської декларації, прийнятої Генеральною асамблеєю Всесвітньої медичної асоціації (1964-2000 рр.), Конвенції ради Свропи про права людини та біомедицину (1997р.) Свропейської конвенції по використанню хребетних тварин для експериментів (1986 р.), відповідні положення ВООЗ, Міжнародної ради медичних наукових товариств та міжнародного кодексу медичної етики (1983р.) та відповідні закони України.

Таблиця 1. Дані про лікарів-неврологів, що прийняли участь у досліджені

\begin{tabular}{|c|c|c|}
\hline Показник & Абс. & $\%$ \\
\hline \multicolumn{3}{|c|}{ Стать } \\
\hline Чоловіча & 34 & 28,6 \\
\hline Жіноча & 85 & 71,4 \\
\hline \multicolumn{3}{|c|}{ Вік } \\
\hline до 30 років & 12 & 10,1 \\
\hline 30-40 років & 16 & 133,4 \\
\hline 40-50 років & 31 & 26,1 \\
\hline 50-60 років & 46 & 38,7 \\
\hline старше 60 років & 14 & 11,7 \\
\hline \multicolumn{3}{|c|}{ Лікарський стаж } \\
\hline до 5 років & 12 & 10,1 \\
\hline від 5 до 10 років & 24 & 21,0 \\
\hline від 10 до 20 років & 30 & 25,2 \\
\hline більше 20 років & 53 & 44,7 \\
\hline \multicolumn{3}{|c|}{ Кваліфікаційна категорія } \\
\hline Вища & 56 & 47,1 \\
\hline Перша & 38 & 31,9 \\
\hline Друга & 21 & 17,6 \\
\hline Сертифікат & 4 & 3,4 \\
\hline
\end{tabular}

Анкети були розроблені з урахуванням принципів паблікрелейшн 3 тим, щоб при найменшій можливій кількості запитань можна було отримати максимум інформації. 
При виконанні дослідження було використано наступні методи: соціологічний та статистичний. Методичною основою дослідження був системний підхід.

\section{Результати дослідження та їх обговорення}

На початку дослідження було вивчено та проаналізовано перша частина анкети яка стосувалася професійної оцінки загальних питань. Отримані результати наведено в табл. 2.
За даними респондентів у 99,3 $\pm 0,4 \%$ випадків стан пацієнтів при їх госпіталізації змінився. При цьому $83,8 \pm 1,9 \%$ опитаних вказали, що стан пацієнтів став більш тяжким, а 16,2 $\pm 1,8 \%$ відмітили, що пацієнти поступають в більш занедбаних станах. За даними опитаних лікарів причиною цьому є: несвоєчасне звернення за медичною допомогою $(52,1 \pm 2,5 \%)$, відміна диспансеризації $(50,4 \pm$ $2,5 \%)$, низький рівень санітарної культури населення $(44,4 \pm 2,5 \%)$, погіршення економічного стану населення $(37,6 \pm 2,4 \%)$, реформування системи охорони здоров'я в місті $(19,7 \pm 2,0 \%)$ тощо.

\section{Таблиця 2. Професійна оцінка загальних питань}

\begin{tabular}{|c|c|c|}
\hline \multirow{2}{*}{ Питання } & \multicolumn{2}{|c|}{ Позитивна відповідь } \\
\hline & абс. & $\%$ \\
\hline Чи змінився за останні роки стан здоров’я пацієнтів при їх госпіталізації & 117 & $99,3 \pm 0,4$ \\
\hline \multicolumn{3}{|l|}{ Якщо змінився, то в який бік (п-117) } \\
\hline більш тяжкий стан, & 98 & $83,8 \pm 1,9$ \\
\hline більш легкий стан & - & - \\
\hline більш занедбані форми захворювання & 19 & $16,2 \pm 1,8$ \\
\hline \multicolumn{3}{|c|}{ На Ваш погляд, що являється причиною погіршення стану здоров’я населення (п-117) } \\
\hline байдуже ставлення до особистого здоров’я & 11 & $9,4 \pm 1,4$ \\
\hline низький рівень санітарної культури & 52 & $44,4 \pm 2,5$ \\
\hline погіршення економічного стану & 44 & $37,6 \pm 2,4$ \\
\hline несвоєчасне звернення за медичною допомогою & 61 & $52,1 \pm 2,5$ \\
\hline реформування системи охорони здоров’я в місті & 23 & $19,7 \pm 2,0$ \\
\hline можливість звернутися до лікаря-спеціаліста виключно за направленням сімейного лікаря & 17 & $14,5 \pm 1,8$ \\
\hline відміна диспансеризації & 59 & $50,4 \pm 2,5$ \\
\hline \multicolumn{3}{|l|}{ Як Ви оцінюєте загальну кваліфікацію сімейних лікарів в місті } \\
\hline достатня & 9 & $7,6 \pm 1,3$ \\
\hline низька & 83 & $69,7 \pm 2,3$ \\
\hline незадовільна & 20 & $16,8 \pm 1,8$ \\
\hline не визначився & 7 & $5,9 \pm 1,2$ \\
\hline \multicolumn{3}{|c|}{ Як Ви оцінюєте з кваліфікацію сімейних лікарів з цереброваскулярних хвороб в місті } \\
\hline достатня & 3 & $2,5 \pm 0,8$ \\
\hline низька & 39 & $32,8 \pm 2,3$ \\
\hline незадовільна & 70 & $58,8 \pm 2,5$ \\
\hline не визначився & 7 & $5,9 \pm 1,2$ \\
\hline \multicolumn{3}{|l|}{ Як Ви оцінюєте технічні можливості сімейної медицини в місті } \\
\hline достатні & 3 & $2,5 \pm 0,8$ \\
\hline низькі & 88 & $73,9 \pm 2,2$ \\
\hline незадовільні & 21 & $17,6 \pm 1,9$ \\
\hline не визначився & 7 & $5,9 \pm 1,2$ \\
\hline \multicolumn{3}{|l|}{ Чи залежить Ваша заробітна плата від показників роботи } \\
\hline так & - & - \\
\hline ні & 119 & 100,0 \\
\hline \multicolumn{3}{|l|}{ Чи змінився рівень Вашої заробітної плати після початку реформи } \\
\hline так & 94 & $80,3 \pm 2,0$ \\
\hline ні & 25 & $19,7 \pm 2,0$ \\
\hline \multicolumn{3}{|l|}{ Якщо так, чи він підвищився (п-94) } \\
\hline так & - & - \\
\hline ні & 94 & 100,0 \\
\hline \multicolumn{3}{|l|}{ Чи задовольняють Вас санітарно-гігієнічні умови праці } \\
\hline так & 18 & $15,1 \pm 1,0$ \\
\hline ні & 96 & $80,7 \pm 2,0$ \\
\hline не визначився & 5 & $4,2 \pm 1,0$ \\
\hline
\end{tabular}


При цьому опитані лікарі відмітили в цілому низький рівень як загальної кваліфікації лікарів так і кваліфікації лікарів 3 надання медичної допомоги при цереброваскулярних хворобах (ЦВХ) та технічних можливостей первинної ланки до надання ефективної медичної допомоги, куди первинно має звертатися за медичної допомоги населення.

Всі опитані респонденти відмітили, що їх заробітна плата не залежить від показників професійної діяльності.
При цьому 80,3 $\pm 2,0 \%$ респондентів вказали на те, що їх заробітна плата за період після початку реформи змінилася, але не збільшилася.

Важливим також $є$ теж, що $80,7 \pm 2,0 \%$ опитаних не задовольняють санітарно-гігієнічні умови праці.

Далі вивчалися та аналізувалися результати другого розділу анкети питання якого стосувалися забезпечення професійної діяльності респондентів. Результати наведено в табл. 3 .

\section{Таблиця 3. Оцінка питань забезпечення професійної діяльності}

\begin{tabular}{|c|c|c|c|}
\hline & \multirow{2}{*}{ Питання } & \multicolumn{2}{|c|}{ Позитивна відповідь } \\
\hline & & абс. & $\%$ \\
\hline \multicolumn{4}{|c|}{ Чи маєте ви можливість цілодобово проводити візуалізацію церебрального патологічного процесу } \\
\hline так & & 32 & $26,9 \pm 2,2$ \\
\hline ні & & 87 & $73,1 \pm 2,2$ \\
\hline \multicolumn{4}{|c|}{$\begin{array}{c}\text { Чи маєте ви можливість цілодобово проводити візуалізацію церебрального патологічного процесу } \\
\text { у вихідні і святкові дні }\end{array}$} \\
\hline так & & 29 & $24,4 \pm 2,1$ \\
\hline ні & & 90 & $75,6 \pm 2,2$ \\
\hline \multicolumn{4}{|c|}{ Чи маєте ви можливість цілодобово забезпечити консультацію пацієнтам лікарем-нейрохірургом } \\
\hline так & & 23 & $19,3 \pm 2,0$ \\
\hline ні & & 96 & $80,7 \pm 2,0$ \\
\hline \multicolumn{4}{|c|}{$\begin{array}{c}\text { Чи маєте ви можливість цілодобово забезпечити консультацію пацієнтам лікарем-нейрохірургом } \\
\text { у вихідні і святкові дні }\end{array}$} \\
\hline так & & 23 & $19,3 \pm 2,0$ \\
\hline ні & & 96 & $80,7 \pm 2,0$ \\
\hline \multicolumn{4}{|c|}{ Чи маєте ви можливість цілодобово забезпечити консультацію пацієнтам лікарем анестезіологом } \\
\hline так & & 41 & $34,5 \pm 2,4$ \\
\hline ні & & 78 & $65,5 \pm 2,4$ \\
\hline
\end{tabular}

Чи маєте ви можливість цілодобово забезпечити консультацію пацієнтам лікарем-анестезіологом у вихідні і святкові дні

\begin{tabular}{|l|c|c|c|}
\hline так & 41 & $34,5 \pm 2,4$ \\
\hline нi & Чи маєте ви можливість безперешкодно забезпечити консультацію пацієнтам лікарем-реабілітологом \\
\hline & 4 & $3,4 \pm 0,9$ \\
\hline так & 115 & $96,6 \pm 0,9$ \\
\hline
\end{tabular}

\begin{tabular}{l|l|c|}
\hline \multicolumn{1}{|c|}{ Чи маєте ви можливість безперешкодно забезпечити консультацію пацієнтам фізичним терапевтом } \\
\hline так & $3,5 \pm 0,8$ \\
\hline нi & 116 & $97,5 \pm 0,8$ \\
\hline
\end{tabular}

Hi

Чи забезпечений заклад охорони здоров’я лікарськими засобами для надання невідкладної (інтенсивної) медичної допомоги пацієнтам з церебральними інсультами

\begin{tabular}{|l|c|c|c|}
\hline так & 114 & $95,8 \pm 1,1$ \\
\hline ні & 5 & $4,2 \pm 1,0$ \\
\hline
\end{tabular}

Чи забезпечений заклад охорони здоров’я лікарськими засобами для лікування пацієнтів 3 церебральними інсультами в необхідному обсязі

\begin{tabular}{|l|r|r|r|}
\hline так & 34 & $28,6 \pm 2,3$ \\
\hline ні & 85 & $71,4 \pm 2,3$ \\
\hline
\end{tabular}

Аналіз отриманих в ході дослідження та наведених в табл. 3 даних вказує на недостатні можливості лікарівневрологів забезпечення якісної та результативної медичної допомоги при церебральних інсультах (ЦІ). Так, мають можливість цілодобово проводити візуалізацію церебрального патологічного процесу $26,9 \pm 2,2 \%$, а 


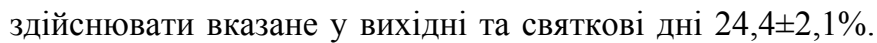
При цьому мають можливість цілодобово так само як у вихідні та святкові дні організувати консультацію пацієнтам лікарем-нейрохірургом $19,3 \pm 2,0 \%$ опитаних. Більш висока частка респондентів цілодобово, включаючи вихідні та святкові дні, має можливість організувати огляд

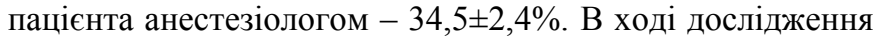
отримані дані які вказують на те, що безперешкодно отримати консультацію спеціаліста із реабілітації респонденти практично не можуть.
За результатами дослідження $95,8 \pm 1,1 \%$ респондентів вказали, що заклад охорони здоров'я забезпечений лікарськими засобами для надання невідкладної (інтенсивної) медичної допомоги пацієнтам 3 церебральними інсультами, а для лікування пацієнтів 3 церебральними інсультами в необхідному обсязі $28,6 \pm 2,3 \%$

Результати третього розділу анкети, що було проведено далі, яким вивчалася оцінка респондентами організаційних питань їх професійної діяльності наведено в табл. 4.

\section{Таблиця 4. Оцінка організаційних питань професійної діяльності}

\begin{tabular}{|c|c|c|c|}
\hline & \multirow{2}{*}{ Питання } & \multicolumn{2}{|c|}{ Позитивна відповідь } \\
\hline & & абс. & $\%$ \\
\hline \multicolumn{4}{|c|}{ Чи мається у лікарні централізована система постачання кисню } \\
\hline так & & 107 & $89,9 \pm 1,6$ \\
\hline ні & & 12 & $10,1 \pm 1,5$ \\
\hline \multicolumn{4}{|c|}{ Чи забезпечені Ви спеціальним одягом для виконання професійних обов’язків } \\
\hline так & & 24 & $20,2 \pm 2,0$ \\
\hline ні & & 95 & $79,8 \pm 2,0$ \\
\hline \multicolumn{4}{|c|}{ Чи ознайомлені Ви з програмою інфекційного контролю та дотримання заходів із запобігання інфекціям } \\
\hline так & & 32 & $26,9 \pm 2,2$ \\
\hline ні & & 87 & $73,1 \pm 2,2$ \\
\hline \multicolumn{4}{|c|}{ Чи мають право відвідувачі пацієнтів відвідувати їх 24 години на добу } \\
\hline так & & 37 & $31,1 \pm 2,3$ \\
\hline ні & & 82 & $68,9 \pm 2,3$ \\
\hline \multicolumn{4}{|c|}{ Чи маються у вашому відділенні стандарти виконання медичними сестрами медичних маніпуляцій } \\
\hline так & & 104 & $87,4 \pm 1,7$ \\
\hline ні & & 15 & $12,6 \pm 1,7$ \\
\hline \multicolumn{4}{|c|}{ Чи достатній рівень практичної підготовки медичних сестер по забезпеченню догляду за хворими на ЦІ } \\
\hline так & & 92 & $77,3 \pm 2,1$ \\
\hline ні & & 27 & $22,7 \pm 2,1$ \\
\hline \multicolumn{4}{|c|}{ Чи існує у відділенні система безперервної професійної підготовки лікарів } \\
\hline так & & 114 & $95,8 \pm 1,0$ \\
\hline ні & & 5 & $4,2 \pm 1,0$ \\
\hline \multicolumn{4}{|c|}{ Чи існує у відділенні система безперервної професійної підготовки середніх медичних працівників } \\
\hline так & & 114 & $95,8 \pm 1,0$ \\
\hline ні & & 5 & $4,2 \pm 1,0$ \\
\hline \multicolumn{4}{|c|}{ Чи навчені молодші медичні сестри прийомам догляду за тяжкохворими пацієнтами } \\
\hline так & & 97 & $81,5 \pm 2,0$ \\
\hline ні & & 22 & $18,5 \pm 1,9$ \\
\hline
\end{tabular}

За наведеними в табл. 4 даними можна констатувати про наявність в закладах охорони здоров'я в яких працюють респонденти певних організаційних проблем. Так, забезпечені спеціальним одягам за рахунок закладу охорони здоров'я 20,2 $2,0 \%$ респондентів, ознайомлені 3 програмою інфекційного контролю та дотримання заходів із запобігання інфекціям 26,9 2 ,2\% опитаних. На право відвідувати пацієнтів 24 години на добу вказало $31,1 \pm 2,3$ респондентів. Позитивним є те, що переважна більшість опитаних вказали на функціонування система безперервної професійної післядипломної підготовки лікарів, середніх та молодших медичних працівників.

Далі, в табл. 5 наведені результати соціологічного дослідження щодо вивчення організаційних питань особистої діяльності лікарів-неврологів. 
Таблиця 5. Оцінка організаційних питань особистої діяльності

\begin{tabular}{|c|c|c|c|}
\hline \multirow{2}{*}{\multicolumn{2}{|c|}{ Питання }} & \multicolumn{2}{|c|}{ Позитивна відповідь } \\
\hline & & абс. & $\%$ \\
\hline \multicolumn{4}{|c|}{ Чи задовольняє Вас процес організації праці в лікарні } \\
\hline так & & 31 & $26,1 \pm 2,2$ \\
\hline ні & & 88 & $73,9 \pm 2,2$ \\
\hline \multicolumn{4}{|c|}{ Чи задовольняє Вас рівень діагностичної служби з надання медичної допомоги пацієнтам із ЦВХ та ЦІ } \\
\hline так & & 24 & $20,2 \pm 2,0$ \\
\hline ні & & 95 & $79,8 \pm 2,0$ \\
\hline \multicolumn{4}{|c|}{ Чи задовольняє Вас рівень забезпечення ліками з надання медичної допомоги пацієнтам із ЦВХ та ЦІ } \\
\hline так & & 22 & $18,5 \pm 1,9$ \\
\hline ні & & 97 & $81,5 \pm 1,9$ \\
\hline \multicolumn{4}{|c|}{$\begin{array}{c}\text { Чи задовольняє Вас рівень забезпечення середнім медичним персоналом } \\
\text { з надання медичної допомоги пацієнтам із ЦВХ та ЦІ }\end{array}$} \\
\hline так & & 17 & $14,3 \pm 1,7$ \\
\hline ні & & 102 & $85,7 \pm 1,8$ \\
\hline \multicolumn{4}{|c|}{$\begin{array}{c}\text { Чи задовольняє Вас рівень забезпечення молодшим медичним персоналом } \\
\text { з надання медичної допомоги пацієнтам із ЦВХ та ЦІ }\end{array}$} \\
\hline так & & 21 & $17,6 \pm 1,9$ \\
\hline ні & & 98 & $82,4 \pm 1,9$ \\
\hline \multicolumn{4}{|c|}{ Чи задовольняє Вас стиль керівництва в лікарні } \\
\hline так & & 36 & $30,3 \pm 2,3$ \\
\hline ні & & 83 & $69,7 \pm 2,3$ \\
\hline \multicolumn{4}{|c|}{ Чи задовольняють Вас професійні відносини в колективі } \\
\hline так & & 102 & $85,7 \pm 1,8$ \\
\hline ні & & 17 & $14,3 \pm 1,7$ \\
\hline \multicolumn{4}{|c|}{ Чи задовольняє Вас моральний мікроклімат в колективі } \\
\hline так & & 91 & $76,5 \pm 2,1$ \\
\hline ні & & 28 & $23,5 \pm 2,1$ \\
\hline
\end{tabular}

Аналіз наведених в табл. 5 даних вказує на те, що $73,9 \pm 2,2 \%$ опитаних не задовольняє процес організації праці в лікарні, $79,8 \pm 2,0 \%$ не задовольняє рівень діагностичної служби 3 надання медичної допомоги пацієнтам із ЦВХ та ЦІ, $81,5 \pm 1,9 \%$ не задовольняє рівень забезпечення ліками 3 надання медичної допомоги пацієнтам із ЦВХ та ЦІ та $85,7 \pm 1,8 \%$ не задовольняє рівень забезпечення середнім медичним персоналом з надання медичної допомоги пацієнтам із ЦВХ та ЦІ. При цьому більшість респондентів задовольняє рівень професійних відносин $(85,7 \pm 1,8 \%)$ та моральний $\quad(76,5 \pm 2,1 \%) \quad$ в колективі.

Узагальнені відповіді на останній розділ анкети наведено в табл. 6.

\section{Таблиця 6. Оцінка додаткових питань, пов'язаних 3 професійною діяльністю та реформуванням системи охорони здоров'я}

\section{Питання}

Позитивна відповідь

абс. $\%$

Як Ви вважаєте, чи покращилися умови надання медичної допомоги пацієнтам іх ЦВХ та ЦІ після початку другого етапу реформ охорони здоров'я у місті

значно покращилися

незначно покращилися

не змінилися

погіршилися

Чи вважаєте Ви, що матеріально-технічна база лікарні забезпечує її функції та відповідає його задачам 3 надання медичної допомоги пацієнтам із ЦВХ та ЦІ

так, повністю забезпечує
4

$3,4 \pm 0,9$ 
майже повністю

лише частково

не дає можливості надавати медичну допомогу у повному обсязі

категорично не відповідає завданням закладу/відділення первинної медичної допомоги

Як Ви оцінюєте загальну професійну підготовку лікарів

для надання медичної допомоги пацієнтам при ЦВХ та ЦІ

\begin{tabular}{l|r|r|}
\hline дуже добра, повністю відповідає задачам & 5 & $4,2 \pm 1,0$ \\
\hline добра & 45 & $37,8 \pm 2,4$ \\
\hline задовільна & 39 & $31,9 \pm 2,3$ \\
\hline потребує покращення & 26 & $21,8 \pm 2,1$ \\
\hline незадовільна & 4 & $3,4 \pm 0,9$ \\
\hline
\end{tabular}

Як Ви оцінюєте загальну професійну підготовку медичних сестер для надання медичної допомоги пацієнтам при ЦВХ та ЦІ

\begin{tabular}{|c|c|c|}
\hline дуже добра, повністю відповідає задачам & 4 & $3,4 \pm 0,9$ \\
\hline добра & 51 & $42,9 \pm 2,5$ \\
\hline задовільна & 21 & $17,6 \pm 1,9$ \\
\hline потребує покращення & 34 & $28,6 \pm 2,3$ \\
\hline незадовільна & 9 & $7,6 \pm 1,3$ \\
\hline \multicolumn{3}{|c|}{ Як Ви оцінюєте загальні результати медичної допомоги пацієнтам на ЦВХ та ЦІ } \\
\hline результати роботи дуже добрі & 2 & $1,7 \pm 0,6$ \\
\hline добрі & 27 & $22,7 \pm 2,1$ \\
\hline задовільні & 46 & $38,7 \pm 2,4$ \\
\hline потребують покращення & 44 & $36,9 \pm 2,4$ \\
\hline незадовільні & - & \\
\hline \multicolumn{3}{|c|}{ Як Ви оцінюєте ставлення медичного персоналу до пацієнтів } \\
\hline ставлення дуже добре & 7 & $5,9 \pm 1,2$ \\
\hline добре & 49 & $41,2 \pm 2,5$ \\
\hline адекватне & 20 & $16,8 \pm 1,9$ \\
\hline потребує покращення & 34 & $28,6 \pm 2,3$ \\
\hline незадовільне & 9 & $7,6 \pm 1,3$ \\
\hline \multicolumn{3}{|c|}{ Чи маєте Ви на роботі персональний комп’ютер } \\
\hline так & 101 & $84,9 \pm 1,8$ \\
\hline ні & 18 & $15,1 \pm 1,8$ \\
\hline \multicolumn{3}{|c|}{ Чи маєте Ви на роботі доступ до системи Інтернет } \\
\hline так & 101 & $84,9 \pm 1,8$ \\
\hline ні & 18 & $15,1 \pm 1,8$ \\
\hline
\end{tabular}

Які з Вашої точки зору існують стимули для підвищення якості та розширення обсягів медичної допомоги пацієнтам із ЦВХ та ЦІ у вашій лікарні

\begin{tabular}{|c|c|c|}
\hline ніяких & 21 & $17,6 \pm 1,9$ \\
\hline моральні & 23 & $19,3 \pm 2,0$ \\
\hline адміністративні & 19 & $15,9 \pm 1,8$ \\
\hline матеріальні & 15 & $12,6 \pm 1,6$ \\
\hline персональна відповідальність за показники роботи & 41 & $34,5 \pm 2,4$ \\
\hline \multicolumn{3}{|c|}{ Чи підтрумуєте Ви наступні напрямки реформи системи надання медичної допомоги населенню } \\
\hline пріоритетний розвиток первинної медичної допомоги на засадах сімейної медицини & 77 & $64,7 \pm 2,4$ \\
\hline формування госпітальних округів & 21 & $17,6 \pm 1,9$ \\
\hline автономізацію закладів охорони здоров’я & 34 & $28,6 \pm 2,3$ \\
\hline запровадження електронної системи охорони здоров'я & 91 & $76,5 \pm 2,1$ \\
\hline запровадження гарантованого державою пакету медичних послуг & 84 & $70,6 \pm 2,3$ \\
\hline систему «гроші ідуть за пацієнтом» & 69 & $57,9 \pm 2,5$ \\
\hline
\end{tabular}


Проведений аналіз наведених в табл. 6 даних вказує на те, що після початку другого етапу реформ охорони здоров'я умови надання медичної допомоги пацієнтам їх ЦВХ та ЦІ не змінилися $(61,3 \pm 2,4 \%)$ та погіршилися $(31,1 \pm 2,3 \%)$, а матеріально-технічна база лікарні у $28,6 \pm 2,3 \%$ випадків не дає можливості надавати медичну допомогу у повному обсязі. Респонденти відмітили, що загальна професійна підготовка лікарів з надання медичної допомоги пацієнтам при ЦВХ та ЦІ $є$ доброю у 37,8 $2,4 \%$, а у $21,8 \pm 2,1 \%$ потребує покращення. Професійну підготовку медичних сестер респонденти відповідно оцінили: $42,9 \pm 2,5 \%$ та $28,6 \pm 2,3 \%$. Загальні результати медичної допомоги пацієнтам на ЦВХ та ЦІ респонденти оцінили в наступний спосіб: дуже добрі - 1,7 $\pm 0,6 \%$,

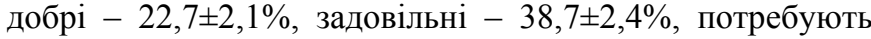
покращення - 36,9 $\pm 2,4 \%$.

Респонденти висловили низький рівень підтримки окремим напрямкам реформи системи охорони здоров'я в країні, що пояснюється їх непоінформованість із зазначених питань.

Перспективи подальших досліджень пов'язані 3 вивченням якості стаціонарної медичної допомоги пацієнтам із церебральними інсультами під час стаціонарного етапу лікування.

\section{Висновки}

Проведений аналіз результатів соціологічного дослідження серед лікарів-неврологів, які надають стаціонарну медичну допомогу пацієнтам при цереброваскулярних хворобах та церебральних інсультах дозволив виявити проблеми організаційного та фінансового порядку, які підлягають рішенню в ході реформування системи охорони здоров'я.

\section{Лiтература}

1. Щорічна доповідь про стан здоров’я населення, санітарно-епідемічну ситуацію та результати діяльності системи охорони здоров’я України. 2015 рік / за ред. Шафранського В. В. ; МОЗ України, ДУ «УІСД МОЗ України». Київ, 2016. - 452 с.

2. Слабкий Г. О. Пріоритетний розвиток первинної медико-санітарної допомоги на засадах сімейної медицини / Г. О. Слабкий, І. С. Зозуля, А. І. Зозуля // Сімейна медицина. - 2014. - № 3 (53). - С. $25-27$.

3. Закон України „Про державні фінансові гарантії медичного обслуговування населення” 19 жовтня 2017 року № 2168-VIII [Електронний ресурс]. Режим доступу: http://search.ligazakon.ua/l_doc2.nsf/link1/T172 168.html. - Haзва 3 екрану.

4. Постанова КМУ „Про затвердження Порядку реалізації державних гарантій медичного обслуговування населення за програмою медичних гарантій для первинної медичної допомоги на 2018 рік” від 25.04 .2018 р. № 407 [Електронний ресурс]. Режим доступу: https://www.apteka.ua/article/458646. - Назва з екрану.

5. Пакети медичних послуг. Зміст та підхід до контрактування закладів охорони здоров'я. Національна служба здоров’я України. - Київ, 2020. - 59 с.

\section{References}

1. Shchorichna dopovid' pro stan zdorov"ya naselennya, sanitarno-epidemichnu sytuatsiyu ta rezul'taty diyal'nosti systemy okhorony zdorov"ya Ukrayiny. 2015 rik / za red. Shafrans'koho V.V. ; MOZ Ukrayiny, DU «UISD MOZ Ukrayiny». - Kyiv, 2016. - 452 s.

2. Slabkyy H. O. Priorytetnyy rozvytok pervynnoyi medyko-sanitarnoyi dopomohy na zasadakh simeynoyi medytsyny / H. O. Slabkyy, I. S. Zozulya, A. I. Zozulya // Simeyna medytsyna. - 2014. - № 3 (53). - S. $25-27$.

3. Zakon Ukrayiny „Pro derzhavni finansovi harantiyi medychnoho obsluhovuvannya naselennya” 19 zhovtnya 2017 roku № 2168-VIII [Elektronnyy resurs]. Rezhym dostupu: http://search.ligazakon.ua/l_doc2.nsf/link1/T172168.html. Nazva z ekranu.

4. Postanova KMU „Pro zatverdzhennya Poryadku realizatsiyi derzhavnykh harantiy medychnoho obsluhovuvannya naselennya za prohramoyu medychnykh harantiy dlya pervynnoyi medychnoyi dopomohy na 2018 rik” vid 25.04.2018 r. № 407 [Elektronnyy resurs]. Rezhym dostupu: https://www.apteka.ua/article/458646. - Nazva z ekranu.

5. Pakety medychnykh posluh. Zmist ta pidkhid do kontraktuvannya zakladiv okhorony zdorov"ya. Natsional'na sluzhba zdorov"ya Ukrayiny. Kyiv, 2020. - 59 s.

Дата надходження рукопису до редакції: 29.05 .2020 р.

Мета роботи: дослідити та проаналізувати рівень оцінки лікарями-неврологами стаціонарної медичної допомоги при церебральних інсультах в закладах охорони здоров'я міста Києва.

Матеріали та методи. Матеріалами дослідження слугували результати соціологічного опитування 119 лікарівневрологів м. Києва які забезпечують надання стаціонарної допомоги пацієнтам при церебральних інсультах. 
Дослідження проводилося за спеціально розробленою анкетою. При виконанні дослідження було використано наступні методи: соціологічний та статистичний. Методичною основою дослідження був системний підхід.

Результати. За даними респондентів у 99,3 $\pm 0,4 \%$ випадків стан пацієнтів при їх госпіталізації змінився: $83,8 \pm 1,9 \%$ опитаних вказали, що стан пацієнтів став більш тяжким, а $16,2 \pm 1,8 \%$ відмітили, що пацієнти поступають в більш занедбаних станах. За даними опитаних лікарів причиною цьому є несвоєчасне звернення за медичною допомогою $(52,1 \pm 2,5 \%)$, відміна диспансеризації $(50,4 \pm 2,5 \%)$, низький рівень санітарної культури населення $(44,4 \pm 2,5 \%)$, погіршення економічного стану населення $(37,6 \pm 2,4 \%)$, реформування системи охорони здоров'я в місті $(19,7 \pm 2,0 \%)$ тощо.

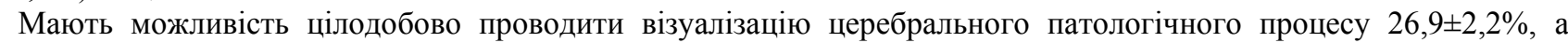

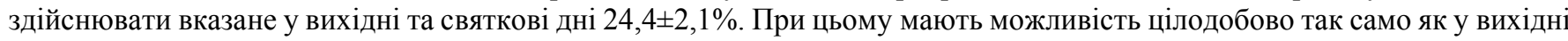

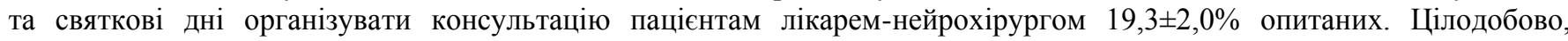
включаючи вихідні та святкові дні, мають можливість організувати консультацію анестезіолога $34,5 \pm 2,4 \%$. 95,8 $\pm 1,1 \%$ респондентів вказали, що заклад охорони здоров'я забезпечений лікарськими засобами для надання невідкладної (інтенсивної) медичної допомоги пацієнтам 3 церебральними інсультами, а для лікування пацієнтів 3 церебральними

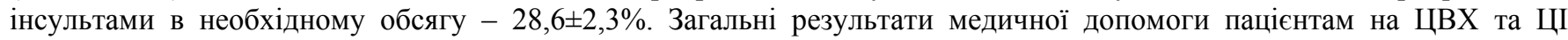

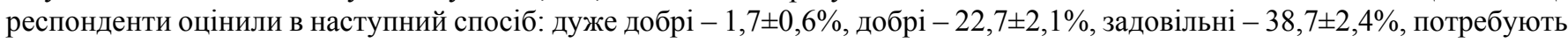
покращення - 36,9 $2,4 \%$.

Висновки. Проведений аналіз результатів соціологічного дослідження серед лікарів-неврологів, які надають стаціонарну медичну допомогу паціснтам при цереброваскулярних хворобах та церебральних інсультах дозволив виявити проблеми організаційного та фінансового порядку, які підлягають рішенню в ході реформування системи охорони здоров'я.

Ключові слова: церебральні інсульти, медична допомога, стаціонари, оцінка, лікарі-неврологи, опитування.

Цель работы: изучить и проанализировать уровень оценки врачами-неврологами стационарной медицинской помощи при церебральных инсультах в лечебных учреждениях города Киева.

Материалы и методы. Материалами исследования послужили результаты социологического опроса 119 врачейневрологов г. Киева, которые обеспечивают оказание стационарной помощи пациентам при церебральных инсультах. При выполнении исследования были использованы такие методы: социологический и статистический. Методической основой исследования стал системный подход.

Результаты. По данным респондентов в $99,3 \pm 0,4 \%$ случаев состояние пациентов при их госпитализации

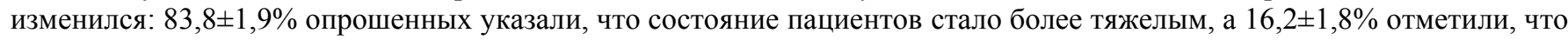
пациенты поступают в более запущенном состоянии. По данным опрошенных врачей причиной этого является несвоевременное обращение за медицинской помощью $(52,1 \pm 2,5 \%)$, отмена диспансеризации $(50,4 \pm 2,5 \%)$, низкий уровень санитарной культуры населения (44,4 $2,5 \%)$, ухудшение экономического положения населения $(37,6 \pm 2,4 \%)$, реформирование системы здравоохранения в городе $(19,7 \pm 2,0 \%)$, и др.

Имеют возможность круглосуточно проводить визуализацию церебрального патологического процесса $26,9 \pm 2,2 \%$, а проводить её в выходные и праздничные дни $24,4 \pm 2,1 \%$. При этом имеют возможность круглосуточно, так же как в выходные и праздничные дни, организовать пациентам консультацию врача-нейрохирурга 19,3 $\pm 2,0 \%$ опрошенных. Круглосуточно, включая выходные и праздничные дни, имеют возможность организовать консультацию анестезиолога $34,5 \pm 2,4 \%$. 95,8 $1,1 \%$ респондентов указали, что лечебное заведение обеспечено лекарственными средствами для оказания неотложной (интенсивной) медицинской помощи пациентам с церебральными инсультами, а

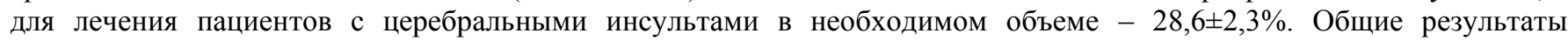
медицинской помощи пациентам с цереброваскулярными заболеваниями и церебральными инсультами респонденты оценили следующим образом: очень хорошие $-1,7 \pm 0,6 \%$, хорошие $-22,7 \pm 2,1 \%$, удовлетворительные $-38,7 \pm 2,4 \%$, требуют улучшения - 36,9 $\pm 2,4 \%$.

Выводы. Проведенный анализ результатов социологического исследования среди врачей-неврологов, которые оказывают стационарную медицинскую помощь пациентам с цереброваскулярными заболеваниями и церебральными инсультами, позволил выявить проблемы организационного и финансового порядка, подлежащие решению в ходе реформирования системы здравоохранения.

Ключевые слова: церебральные инсульты, медицинская помощь, стационары, оценка, врачи-неврологи, опрос.

Goal of research: to study and analyze the level of neurologists' assessment of in-patient medical care for patients with cerebral stroke in Kyiv health care establishments.

Materials and methods. The results of a sociological survey of 119 Kyiv neurologists who provide in-patient care to patients with cerebral stroke were used as the materials of research. Sociological and statistical methods were applied in the course of study. Systematic approach became the methodological basis of the study.

Results. According to the respondents in $99,3 \pm 0.4 \%$ of cases the condition of patients after their hospitalization has changed: $83.8 \pm 1.9 \%$ of the polled persons indicated that the patients' condition was harder, and $16.2 \pm 1.8 \%$ noted that patients are found in more abandoned condition. According to the polled doctors, the reason for this is untimely treatment $(52,1 \pm 2,5 \%)$, 
the abolition of prophylactic medical examination $(50,4 \pm 2.5 \%)$, the low level of the population sanitary culture (44.4 $\pm 2.5 \%)$, deterioration of the economic state of the population $(37,6 \pm 2.4 \%)$, health care system reforming in the city, etc.

$26.9 \pm 2.2 \%$, have a round-the-clock visualization of the cerebral pathological process and $24.4 \pm 2.1 \%$ can carry that out including weekends and holidays. At the same time $19.3 \pm 2.0 \%$ of the polled have the possibility to organize consultation of doctor-neurosurgeon for patients 24 hours a day as on weekends and holidays. 34,5 $\pm 2.4 \%$ have possibility to organize anesthesiologist's consultation 24 hours a day, including weekends and holidays. 95,8 $\pm 1.1 \%$ of respondents indicated that the health care establishment is provided with medicinal products for emergency (intensive) care to patients with cerebral strokes, and $28,6 \pm 2.3 \%$. for the treatment of patients with cerebral strokes in the required volume. The general results of medical care to patients with cerebrovascular diseases and cerebral strokes were assessed by the respondents in the following way: very good $1.7 \pm 0.6 \%$, good $-22,7 \pm 2.1 \%$, satisfactory $-38,7 \pm 2.4 \%$, require improvement $-36,9 \pm 2.4 \%$.

Conclusions. The undertaken analysis of the results of sociological research among doctors-neurologists, who provide in-patient medical care to patients with cerebrovascular diseases and cerebral strokes, has allowed to identify the problems of organizational and financial character that are subject to decision in the course of healthcare system reform.

Key words: cerebral stroke, medical care, in-patient departments, assessment, neurologists, survey.

\section{Відомості про автора}

Прокопів Марія Мирославівна - к.мед.н., доцент, доцент кафедри неврології Національного медичного університету імені О.О. Богомольця; м. Київ, бул. Т. Шевченка, 13.

prokopivmm@gmail.com. 